of the relatively narrow range of PR sampled; (3) In selecting items equal on two attributes (AV and frequency) but differing on a third (PR), someitems might be picked whose peculiar attributes make their scaling unreliable. The finding of a PR effect in the present study with identical items, while not discounting possible influences of the latter two factors, suggests that list construction is an important variable affecting $P R$ results.

\section{References}

Braud, W. G., Tolin. P.. \& Holbom, S. W. Pronounciability rating and learning of doubly homogeneous paired-associate lists. Psychon. Sci., 1966, 6, 457-458.

Lindley. R. H. Association value, familiarity, and pronounciability ratings as predictors of serial verbal learning. J. exp. Psychol., 1963, 65, 347-351.

Postman, L. Extra-experimental interference and the retention of words. J. e.rp. Psychol., 1961, 61, 97-110.

Underwood, B. J., \& Schulz, R. W. Meaningiulness and verbal learning. Chicago: Lippincott, 1960.

\title{
Comment on developmental level and concept learning: A possible artifact by H. E. Klugh
}

Te Vault et al (1966) question the interaction of age and intellectual ability reported by Klugh et al (1964, 1965), Friedman (1965), and Pishkin \& Rosenbluh (1966).

Their data are based on a study in which 40 children in each of two age groups are randomly assigned to five experimenters and two types of problem conditions. This yielded a 2 by 2 by 5 design with four Ss in each cell. Te Vault et al report, "The conditions $(F=12.50$, $\mathrm{df}=1 / 780)$ and Experimenters $(\mathrm{F}=9.24, \mathrm{df}=4 / 780)$ main effects, and the Experimenters by Conditions and Experimenters by Conditions by Age interaction ( $F=$ 3.39 , $d f=4 / 780$ and $F=3.75, d f=4 / 780$ ) were all significant at the .01 level of confidence."

The investigators determined that the significant conditions effect and the significant interactions were due to one "deviant experimenter." When this investigator's data were dropped and the result reanalyzed, the only significant remaining effect was among experimenters. Te vault et al concluded, among other things, that "... significant effects of the type reported by Klugh et al, Friedman, and by Pishkin and Rosenbluh can be produced merely by experimenter differences."

Te Vault's conclusions may be true, but they do not necessarily follow from his analysis because he seems to have used an inappropriate error term for testing the significance of the main effects and their interactions. Te Vault gave each of the Ss 10 trials (personal communication) yielding a total of 799 df for the study. His error term, based on $780 \mathrm{df}$, is apparently the result of pooling the sums of squares between Ss in the same cell $(\mathrm{df}=60)$, which is the appropriate error term, with the sums of squares between trials $(\mathrm{df}=9)$ and the total Ss by Trials interaction $(\mathrm{df}=711)$. Since the effects reported are based entirely on variation between $\mathrm{Ss}$, the appropriate error sum of squares should be that between $\mathrm{Ss}$ in the same cell, and thus has just $3 \mathrm{df}$ for each of the 20 cells, yielding a total of $60 \mathrm{df}$.

It then seems possible that the experimental artifact against which $\mathrm{Te}$ Vault cautions is, in this instance, the result of an incorrectly applied analysis of variance.

\section{References}

Friedman, S. R. Developmental level and concept learning: Confirmation of an inverse relationship. Psychon. Sci., 1965, 2, 3-4.

Klugh, H. E., Colgan, K., \& Ryba, J. A. Developmental level and speed of relational concept formation: A possible inverse relationship. Psychon. Sci., 1964, 1, 89-90.

Klugh, H. E., \& Roehl, K. Developmental level and concept learning: Interaction of age and complexity. Psychon. Sci., 1965, 2, 385-386.

Pishkin, V., \& Rosenbluh, E. S. Concept identification of auditory dimensions as a function of age and sex. Psychon. Sci., 1966, $4,165-166$.

Te Vault, R. Kent, Bailey, Melinda, Cagan, Elizabeth, Diones, Joan, \& Figelman, Edith. Developmental level and concept learning: A Possibie Artifact. Psychon. Sci., 1966, 5, 167-168.

\section{Developmental level and concept learning: Reply by $R$. Kent Te Vault}

As Professor Klugh has pointed out in his comment, the analysis of variance reported earlier by us (1966) was in error. The unfortunate use of the incorrect error term occurred in the course of rewriting and shortening a longer paper. The statistical error is a real one and ought to be recognized. At the same time it should be pointed out that the statistical error does not in any way alter the conclusions drawn.

\section{Reference}

Te Vault, R. Kent, Bailey, Melinda, Cagan, Elizabeth, Diones, Joan, \& Figelman, Edith. Developmental level and concept learning: A possible artifact. Psychon. Sci., 1966, 5, 167-168. 